\title{
Uso da ultrassonografia como ferramenta auxiliar no diagnóstico da tuberculose bovina
}

Valesca Henrique Lima ${ }^{[a]}$, Nivan Antonio Alves da Silva ${ }^{\left[{ }^{[a]}\right.}$, Rodolfo José Cavalcanti Souto ${ }^{[a]}$, Maria Isabel de Souza[a], Nivaldo de Azevedo Costa ${ }^{[a]}$, Jobson Filipe de Paula Cajueiro ${ }^{[a]}$, José Augusto Bastos Afonso ${ }^{[a]}$, Carla Lopes de Mendonçąa ${ }^{[a]}$, José Cláudio Almeida de Souza ${ }^{[b]}$, Luiz Teles Coutinho[a]"

[a] Clínica de Bovinos, Universidade Federal Rural de Pernambuco (UFRPE), Garanhuns, PE, Brasil

[b] Unidade Acadêmica de Garanhuns, Universidade Federal Rural de Pernambuco (UAG/UFRPE), Garanhuns, PE, Brasil

*Autor correspondente

e-mail: luiz.coutinho@ufrpe.br

\section{Resumo}

A tuberculose bovina é uma doença infectocontagiosa, crônica e progressiva, caracterizada por formações granulomatosas típicas - tubérculos - mais frequentemente observadas nos linfonodos, pulmões, intestinos, fígado, baço, pleura e peritônio. Além do seu caráter zoonótico, é responsável por consideráveis prejuízos econômicos e sociais, em virtude do impacto negativo na produtividade dos rebanhos e dos riscos que acarreta à saúde humana. 0 objetivo desse trabalho foi avaliar a ultrassonografia como ferramenta auxiliar no diagnóstico da tuberculose bovina, como também descrever os principais achados clínico-laboratoriais e anatomopatológicos de cinco bovinos, portadores da enfermidade, atendidos na Clínica de Bovinos, campus Garanhuns, Universidade Federal Rural de Pernambuco. Esses animais foram submetidos ao exame físico e amostras de sangue foram coletadas para realização de hemograma, determinação plasmática da proteína e do fibrinogênio. A ultrassonografia foi realizada com os animais em estação e sem sedação, nos dois antímeros da região torácica e na região hepática do antímero direito, utilizando-se equipamento Z6Vet, da marca Mindray, com probe convexa multifrequencial modelo 3C5P, com frequência de 5,0 MHz. 0 exame físico revelou baixa condição corporal, comprometimento dos sistemas cardiorrespiratório e digestório e, na exploração retal de alguns animais, havia a presença de nodulações firmes sobre a serosa de diversos órgãos. No hemograma houve leucocitose por neutrofilia e hiperproteinemia. A ultrassonografia demonstrou imagens delimitadas, de formato nodular, isoladas e/ou agrupadas, com conteúdo de diferentes padrões de ecogenicidade, variando do anaecóico até o hiperecóico, homogênio ou heterogênio. Em função da gravidade da condição clínica, os animais foram eutanasiados e encaminhados para necropsia, onde fragmentos de órgãos com presença de lesões foram coletados, fixados em formol a 10\% e enviados para exame histopatológico. Macroscopicamente observou-se nódulos firmes, amarelos acinzentados (granulomas), em número e tamanho variados, isolados 
e/ou coalescentes; ao corte, o conteúdo necrótico e/ou caseoso conferia a clássica impressão de "ranger ao corte". Os órgãos mais acometidos foram pulmão e linfonodos (100\%); peritônio, omento e serosas (80\%); fígado, rins, pleura, diafragma e coração (40\%); e baço, intestinos e traqueia (20\%). 0 exame histológico revelou a formação de tubérculos em diferentes estágios de desenvolvimento, possuindo células epitelióides e células gigantes de Langhans, com ou sem calcificação. 0 confronto das imagens ultrassonográficas com os achados anatomopatológicos revelou que as lesões foram correlatas e compatíveis em suas localizações anatômicas, dimensões e características teciduais, demonstrando que a ultrassonografia foi eficiente como ferramenta auxiliar no diagnóstico da tuberculose bovina e deve ser utilizada em conjunto com um método diagnóstico confirmatório. 